UDC 766
DOI https://doi.org/10.24919/2308-4863/43-1-10

Ganna GOLUBNYCHA, orcid.org/0000-0002-0309-4714

Doctoral Student at the Department of Design and Technologies Kyiv National University of Culture and Arts (Kyiv, Ukrane)ann.golubnycha@gmail.com

\title{
ARTISTIC AND IMAGINATIVE PROPERTIES OF GENDER INFOGRAPHICS
}

Gender social infographics is becoming widespread as a tool of visual communication at the international level. The purpose of the article is to characterize artistic and imaginative specifics that is representative in gender social infographics; to identify compositional and component features of such infographic projects; to describe scientifically the nature of the visual code of elements of design visualization of gender-specific content; to classify symbiotic infographics, which are hybrids of symbols and diagrams. In this article, complex research methods of the empirical vector (scientific comparison) and the theoretical vector (analysis, synthesis, inductive and deductive techniques) are applied in the design aspect. The concept of gender infographics is introduced into the scientific design terminology. For the first time, the artistic and figurative specificity, graphic design of exclusive components, chromatic, plastic and symbolic coding of social information graphics of the gender vector are highlighted. The concept of hybrid diagrams is introduced by the author, which are further classified by visual characteristics. Conclusions. The general stylistic trends of gender infographics in recent years are described. The article identifies the patterns of building a typographic system on which this type of information graphics is based. The graphic features of gender symbols and variations of their application within the framework of an infographic product are considered. The variety of options for the colour semantic range of gender infographics is described. A classification of gender hybrid diagrams is proposed to potentiate the artistic-figurative variety of design visualization of data arrays. The influence of visual metaphors on the level of information content of an infographic product is revealed. The specificity of the synchronism of visual processing of graphic and text elements of infographics is explained. Solutions are proposed to avoid design mistakes associated with the subjectivity of personal perceptual experience.

Key words: gender infographics; artistic and imaginative instruments; designer visualization; hybrid diagrams; visual metaphors; gender symbols.

Ганна ГОЛУБНИЧА, orcid.org/0000-0002-0309-4714 аспірант кафедри дизайну і технологій Київського національного університету культури і мистецтв (Київ, Україна) ann.golubnycha@gmail.com

\section{ХУДОЖНЬО-ОБРАЗНІ ВЛАСТИВОСТІ ГЕНДЕРНОЇ ІНФОРМАЦИЙНОЇ ГРАФІКИ}

Гендерна соиіальна інфографіка набуває широкого розповсюдження як інструмент візуальних комунікацій інтернаціонального рівня. Мета статті - охарактеризувати репрезентативну для гендерної соціальної інфографіки художньо-образну специфіку; виявити композичійні та компонентні особливості подібних інфографічних проєктів; науково описати характер візуального коду елементів дизайнерської візуалізаиії контенту гендерної спрямованості; класифікувати симбіотичні інфографічні складники, щчо є гібридами символів і діаграм. У статті застосовані комплексні дослідниџькі методи емпіричного вектора (наукове порівняння) і теоретичного вектора (аналіз, синтез, індуктивні та дедуктивні прийоми) в дизайнерському аспекті. У науковий дизайнерський термінологічний апарат уводиться поняття гендерної інфографіки. Уперше висвітлюється художньо-образна специффіка, графічне конструювання ексклюзивних компонентів, хроматичне, пластичне і символьне кодування сочіальної інформаційної графіки гендерної спрямованості. Уводиться поняття гібридних діаграм, які класифікуються за візуальними характеристиками. Описано загальні стилістичні тенденції гендерної інфографіки останніх років. Виявлено закономірності побудови типографічної системи, на яких базується даний вид інформачійної графіки. Розглянуто графічні особливості гендерних символів і варіації їх застосування в межах інфографічного продукту. Описано різноманітність опиій колірного семантичного ряду гендерної інфографіки. Запропоновано класифікаџію гендерних гібридних діаграм для потенціювання художньо-образної різноманітності дизайнерської візуалізачії масивів даних. Виявлено вплив візуальних метафор на рівень інформативності інфографічного продукту. Пояснена специфіка синхронності візуальної обробки графічних і текстових елементів інфографіки. Запропоновано рішення для уникнення дизайнерських помилок, пов'язаних із встановленням суб 'єктивного особистісного перцептивного досвіду.

Ключові слова: гендерна інфографіка, художньо-образні інструменти, дизайнерська візуалізачія, гібридні діаграми, візуальні метафори, гендерні символи. 
The problem statement. Recently, in the global information field, there has been a significant interest in social infographics, in particular, of the gender vector, however, with a detailed analysis of such instances, there are some flaws in infographic visual systems that affect the assimilation of the key messages. The study of artistic and imaginative properties characteristic of gender infographics is an extremely important stage of design comprehension for the further high-quality development of an infographic project that will have a high level of informational content and a factor of unhindered decoding of an infographic message in order to achieve the goal of educating the population about the socially significant positions of gender interaction at different cultural levels.

Recent research and publication analysis. Primary basic research papers on information graphics include Heer (2008) and Smicklas (2012), which represent the essence of design infographic visualization knowledge in analytical, communication and executive aspects. Some informative and aesthetic features of social graphics were studied by Bozhko, Golubnycha (2021), and specifically, the specificity of artistic-figurative gender neutrality in information graphics is described in the work of Vezhbovska, Golubnycha (2019). Elam (2009) researched, determined and classified typographic systems of design compositions. Van den Reek (2010) studied the human-induced effect of introducing visual metaphors into an artistic product and the various ways in which they are combinatorially and interractively processed by consciousness. Patry (2012) demonstrated artistic linguistic constructions, techniques that were borrowed into the visual mode to the scientific community. Young (2003) described the properties of the product of art as rewarding experience through sensory contemplation of visions and the emergence of insights in his book. FaroqiShah, Gehman (2021) investigated the processes of perception of words by the human visual system, their identification and decoding. Thorpe (1991), Thorpe et al. (1996) are the scientific publications that reveal the core of the phenomenon of processing various types of images by the human brain and the functioning of its area of the visual system.

Purpose of the article. The purpose of the article is to systematize the artistic and imaginative tools of infographic design of the gender vector to identify the most effective and appropriate methods for developing social infographics, in particular, of gender type, to maximize the applied effectiveness and avoid typical mistakes of design creation.

The main part of the article. Infographics is a visual representation of graphic information, certain data sets or individual knowledge, which is developed for quick and clear understanding and assimilation of information (Smiciklas, 2012: 23-39), it is a separate genre of visual communications segment, which combines data visualization, illustrations, the minimum amount of text, general signs and embedded information in one project in order to create an interesting, informative description of a particular situation, informational block or story. Scientists attribute infographics to a variety of graphic and communication design, the property of infographics is the ability to improve cognition by using graphic images to deepen the ability of the human visual system to recognize individual patterns and trends (Heer et al., 2008: 1189-1196).

Gender infographics is a separate type of social infographics, which addresses issues of gender interaction, such infographics are designed to partially transform the worldview in the direction of equality and dignity of both women and men.

Social infographics is a distinct category of infographics, it has an inherent component of informative or informative-motivational nature and inducement to action. The humane vector of world change and the focus on the positive actualization of individuum as a member of society are the goals of social infographics (Bozhko, Golubnycha, 2021: 19-23).

As part of the study of gender infographics, the author analyzed 27 infographic samples in detail, which fulfilled the principle of sufficiency in order to formulate artistic and imaginative features of infographics on gender topic.

The analysis of these infographic examples showed that the design visualization of socially significant gender-related information arrays implies a wide range of application of various visual communications techniques.

A certain number of patterns were identified in infographic designs, such as the prevailing use of sans-serif fonts (optimal use in one infographic composition is a maximum of two typefaces with variable styles); the use of ranking headings in titles to underline importance and information subordination; the use of colour techniques, nuances and contrasts, when highlighting certain information; the implication of complementary colour solutions to emphasize the differences of feminine and masculine nature, as well as colour similarity to emphasize the affinity of deterministic properties. Also, gender information graphics are characterized by the involvement of hybrid diagrams and the use of visual metaphors.

The modular arrangement of graphic elements, a variety of modular typographic systems in infographic format are preferable for gender infographics. 
The figurative symbols that are present in the infographic composition, which illustrate a certain situation or action, play an important role in keeping attention on the embedded meaning, they are characterized by simplicity of forms, the absence of stroke outlines, these tendencies are common to the world dynamics in graphic design.

Highly desirable elements of gender infographics are signatures of sources of reliable information that is represented.

In this type of infographic, in some cases, it is customary to combine vector and raster graphics, such as photographic images.

In order to achieve a harmonious perception of gender infographics, graphic designers take into account the nominal rules for building a composition, adhere to a visual storyline, since information graphics is a visualized story.

An important aspect that can be traced in the vast majority of examples of gender-related information graphics is adherence to a single style of visualization, which is the leitmotif of the infographic complex, in order to maintain resonance with the audience to whom the infographic product is demonstrated.

All analogs of information graphics, considered in the framework of scientific research, reflect postmodern sentiments, graphic designers reject rigid canons with strict value structuring, which are the characteristic of the aesthetic spectrum, in their designs there is a deconstruction of the classical rules of graphic design, which were based on brevity, hierarchy and orderliness of the Bauhaus and Swiss Style currents. Also, in gender infographics, the freedom of creative visualization is clearly traced, in which there are no clear boundaries and artistic standards, there is a provocation of socially sensitive issues, a craving for clear answers, involvement in the current moral.

The author of the article proposes to consider the features of gender infographics in more detail to reveal all the artistic and imaginative specifics.

The combination of graphic components according to the principles of building a modular typographic system in gender infographics is based on the structural system (Elam, 2009: 87-104).

Gender-related infographics, which are designed according to the principles of a modular typographic system, have a number of the following advantages, such as unimpeded recognition and an understandable hierarchy of information, a clear visual compositional rhythm, which can optionally perform a metamorphosis of its proportions, this is the so-called "adaptive design" in the case of printing project on an area of different formats or displaying on screens with different resolution settings.
The types of graphical representation of infographics and gender data embedded in it logically reflect the nature and type of information primer that should be infographically encoded.

The aspect of data and the way information is presented directly correlates with the nature and type of verbal information that precedes the design of gender infographics.

It means that with the transition to a qualitative expansion of the variability of gender studies, it is likely that the level of professional visualization of the infographic diversity of gender orientation will significantly increase due to the fact that the palette of artistic and imaginative tools of specialists in the field of visual communications, graphic designers in particular, depends on the complexity and the variety of tasks assigned to them.

The author of this article found that in the gender information graphics there is a significant number of explanatory symbols, which she conventionally divides into two groups, procedural and identifying.

Most often, procedural symbols graphically represent an object or a whole group of conceptually related objects that depict the process in a dynamic or static illustration, this process becomes clear to the viewer due to the logical connection of the grouped constituent elements.

The visual dynamics of procedural symbols becomes possible by introducing the plasticity of forms and individual contours, including the option of tilting the graphic elements relative to the compositional axes, as a result of which a conditional diagonal of the symbol's composition arises.

Such symbols can be inscribed in the outer closing contour of various regular geometric shapes, which is done to give a certain completeness, or to restrict from other graphic information blocks.

Procedural symbols are characterized by the image of actions of a gender-stereotyped nature, for example, duties or gender-accepted responsibilities; next to these symbols, textual explanatory presentation of information of various kinds is usually developed. A frequent case is the disclosure of the infographic plot of the transmitted series of information regarding the feminine symbols of the procedural type due to the fact that the actual problems of gender interactions are described precisely with their help.

Gender pictograms (gender identifying symbols) in infographic examples are represented by a variety of variable images, in most cases they are presented in the form of symbols of Venus and Mars, which are internationally accepted symbols and do not follow to discrepancies, as well as in the form of female and male stylized figures. These characters are decoded 
using graphic gender attributes such as hair, haircut, clothing, and accessories.

The author came to the conclusion that information graphics on gender issues in recent years (approximately 2018-2021) is characterized by the presence in the infographic composition of hybrid bar and radial diagrams (according to the author's proposed classification).

The author of this article introduces the following explanations: a hybrid bar diagram of the first type is an artistic and figurative symbiosis of a symbol that describes a certain qualitative indicator of data, and a bar diagram that is inscribed in this symbol with individual quantitative informative proportions of certain characteristics related to the above symbol.

Simple gender hybrid bar diagrams of the first type are characterized by gender identity and symbolized data (figure 1). It is important that with a graphically complex outline of such diagrams, the visual accuracy of the proportions of information parameters is preserved.

Complex gender hybrid diagrams of the first type represent more systematic and detailed informational parameters in a complex, which are integrated into the symbolic form of such a diagram (figure 2).

Gender hybrid bar diagrams of the second type are those diagrams in which the smallest modulus of each individual quantitative indicator reveal an individual symbolic manifestation, such as chromatic in simple diagrams, figurative, or figurative-chromatic in complex diagrams (figure 3). These diagrams can be designed both vertically and horizontally.

A certain nuance of constructing hybrid diagrams of the second type is proportional convention in the case when the minimum module of the diagram represents a sufficiently large quantitative amount of data. It means that it is appropriate to use these diagrams in a situation of illustrating clear quantitative proportional information (such as an indicator: 1 of 4 women).

Also, in some samples of gender information graphics, one can observe the presence of hybrid radial diagrams (figure 4).

The information activity basis of gender infographics is comparison, similarity and contradistinction of data sets.

A classic case of gender infographics is the informational interaction of feminine and masculine data.

Informational comparison in gender infographics occurs through the comparative presentation of situational quality indicators of feminine and masculine vectors.

The contradistinction in infographics on gender is due to: a) demonstration of differences in quantitative indicators of feminine and masculine nature of one

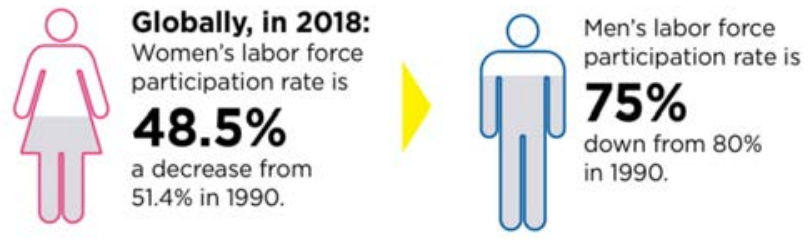

Figure 1. Simple hybrid bar diagrams (I type). Fragment from "Blindness to Gender Bias" infographics.

Source: https://www.peoplemattersglobal.com/article/compensationbenefits/infographic-blindness-to-gender-bias-21058

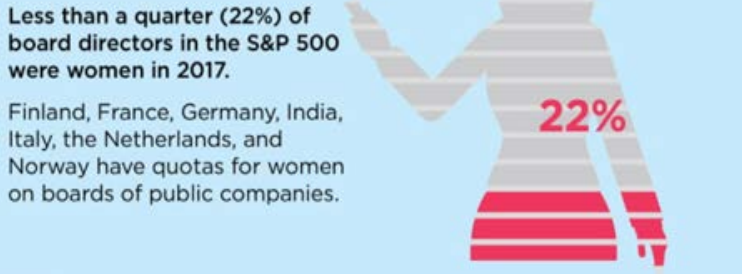

Figure 2. Complex hybrid bar diagrams (I type). Fragment from "Blindness to Gender Bias" infographics.

Source: https://www.peoplemattersglobal.com/article/compensation-benefits/ infographic-blindness-to-gender-bias-21058

\section{IN 4 TEENAGE GIRLS ARE \\ PREGNANT OR HAVE A CHILD}

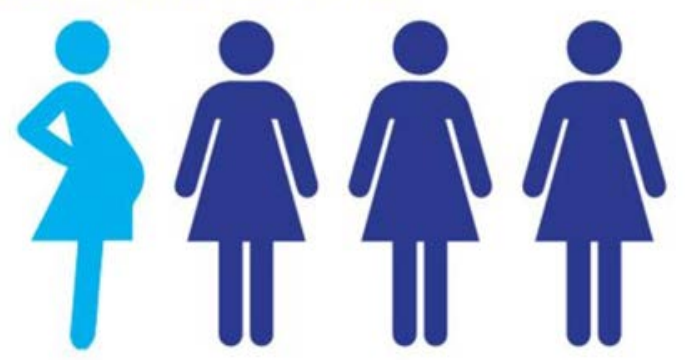

Figure 3. Complex hybrid bar diagrams (II type). Fragment from "Adolescent Girls Are Very Vulnerable" infographics.

Source: UNICEF

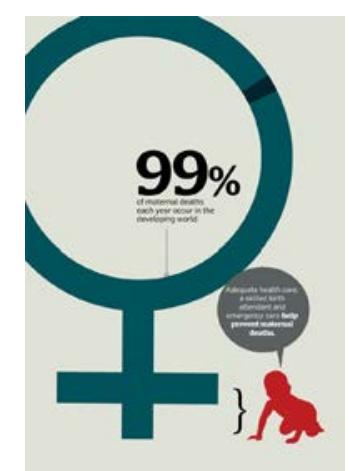

Figure 4. Hybrid radial diagram. Fragment from "Why Invest in Women?" infographics.

Source: https://www.pinterest.com.au/pin/721772277752738615/ 
type of data; b) indicativeness of opposite proportions of quantitative indicators within a particular gender.

The visualized similarity of information is infographically carried out with the help of scientific information blocks of the same gender, these blocks are located side by side, in optical proximity.

Various types of gender information interaction can be presented together within the framework of one infographic project when there is a need for visual coding of complex and multidimensional information. In this case, it is necessary to carefully approach the stage of thinking through a visual idea and the possibilities of competent use of a complex of artistic and imaginative graphic design tools.

Gender properties of certain information blocks are expressed in the presentation of archetypal symbols: feminine attributes are encoded by the fluidity of shapes and outlines of symbolic components, feminine accessories and gender identifiers; the graphic expression of masculine attributes can be traced in the brevity of the constituent symbols, which, of course, represent classically masculine gender characteristics.

Among examples of gender infographics, there are cases of controversial presentation of symbolic data: in some infographic instances, masculine silhouettes are depicted in a larger size, more visually dominant, these cases can lead to a biased perception of gender properties, therefore, when developing gender infographics, direct transfer of real physical dimensions should be avoided and it is important to carefully approach gender stylization. An exception to the use of oversized gender silhouettes, both female or male, is the representation of quantitative data in hybrid diagrams, in which the symbol serves as the spatial filling of the prevailing quantity metric.

Gender indicators of femininity and masculinity in the information graphics are encoded, inter alia, in a chromatic way, in this case, both methods of complementary and near-complementary colouring are used (for indicative contrast). A common occurrence in gender infographics is the use of a gender-identified set of colours (shades of blue and pink). However, gender-neutral colour coding is also widespread in progressive infographics (Vezhbovska, Golubnycha, 2019: 108-113). Masculine data are mainly described using cold shades, feminine ones - using warm ones.

Gender information graphics actively use visual metaphors, which are introduced in order to broadcast the message that the object has certain characteristics that can be obtained from the interpretation of the relationship with another object-resource.

In gender infographics, there are three metaphorical structures: juxtaposition (increasing in complexity, comparison), fusion, and replacement (Van den Reek, 2016: 1-72).
In design data visualization, juxtaposition is used to evoke a certain reaction in the viewer's mind, such as creating meaning from contrasting elements.

Colour juxtaposition in information graphics is used to create contrast, while the location of certain types of objects on top of each other or different types of symbolic components in close proximity to each other is intended to encourage meaning (Young, 2003: 81-120).

Fusion is a technique characterized by a "combination, seemingly incompatible", is a metaphorical combination of completely different ideas, seemingly incompatible associatively, without losing integrity and harmony, and thus creating a completely new logical and semantic order.

Replacement is a visually metaphorical technique that is used when, at the required level of recognition, one object is replaced by another, while maintaining a stable associative series.

The vast majority of examples of gender information graphics are made in a minimalist style. Minimalism in infographic design is based on the following principles: the development of simplicity, the value of neutrality, achieving balance, establishing a hierarchy, the conquest of negative space ("Less Is More, or How Minimalism Changed Graphic Design").

Simplicity plays a crucial role in attracting the observer's attention and in helping to understand the infographic product. To achieve these goals, the minimum possible number of elements in the infographic composition is used.

The visual hierarchy helps observers to follow the planned sequence of elements, letting them know which pieces of information should be considered first, second, third. Design elements, such as colour, size, composition and typography, play an important role in establishing a hierarchy and assigning visual priorities.

One of the most interesting design elements, especially important in minimalist design, is the negative space. Although it is often white, it can also be any other colour. Minimalism involves planning a large amount of negative space in the design to help balance and emphasize other hierarchically aligned design elements ("Less Is More, or How Minimalism Changed Graphic Design").

The average human brain identifies a complex image at a glance for 100-150 ms (Thorpe, 1991: 309-341), (Thorpe, 1996: 520-522), while the value of the word cascade is read by a person for a longer period of $600 \mathrm{~ms}$ (Faroqi-Shah, Gehman, 2021: 949-964).

These scientific data mean that when rapidly, briefly scrolling or viewing information graphics both on a computer screen and in analog form, there 
is a high probability that text signatures will not be read due to the time limit for decoding, and only infographic product images will be identified.

Hence the problems of figurative and semantic synchronization of symbolic and textual elements of gender infographics in separate assimilation, ie: text captions should to some extent reveal the embedded meaning demonstrated in symbols with a certain degree of disclosure, there must be logical-semantic resonance between symbols and texts so that that the perception of the correct infographic message was kept separately, thus excluding discrepancies of text and symbolic components.

There is also a moderate probability of including gender-associated coding errors in the developed gender infographic and subsequent double message.

An example of such coding is the use of genderidentified colours, pink and blue. Even with a skillful infographic explanation of the progressive and modern gender situation, the primer of socially constructed formats of femininity and masculinity remains fixed at the level of archetypes in connection with the use of these colour solutions, because information that had an emotional impact on personality in childhood prevails current information from external sources, obtained in adulthood (Patry, 2012: 56-79).

Analyzing gender infographic analogues, one cannot neglect the fact that in modern infographic design there is the human factor to a certain extent: since the psychological perception of colour decisions and visual images depends on the cultural code, social cliches and personal attitudes, it is likely that with a certain risk of coding errors, the designer may collide, relying solely on his personal preferences and unconscious choices, neglecting the design study of cultural differences in the nature of shapes, colours, psychological properties of fonts, outlines and other elements for maximal correct infographic coding.

In this regard, it is advisable to propose the use of a more appropriate and progressive instrumental approach to design creation, in which a specialist consciously and rationally "programs" infographics using an arsenal of artistic and imaginative techniques to achieve the assigned tasks to minimize the consequences of the dominant type of gender relations, moving away from subjective vision in favor of the objective.

Conclusions. Techniques for creating conceptually multidimensional hybrid diagrams of different types have a significant potential for gender infographics due to the unlimited possibilities of developing their symbolic form, which determines the objective artistic and semantic uniqueness of each hybrid diagram.

Combinatorial design infographic techniques within the framework of a unified single product make it possible to achieve multilevel nested information blocks and the depth of their possible cognition, thereby increasing the graphical and verbal saturation of gender information graphics.

Also, the integration of visual metaphors into an infographic project has a high application potential, since these transitive artistic techniques open up a wide range of possibilities for information coding of complex data for assimilation at an intuitive, subconscious level of visual information processing.

The principles of infographic design in a modular typographic system format and general tendential compliance with a minimalism style are broader guidelines for infographic design not only for gender informational graphics, but also for the basic category of social infographics.

\section{BIBLIOGRAPHY}

1. Божко Т.О., Голубнича Г.В. Взаємозв’язок естетичності й інформативності соціальної інфографіки. Філософія подієвої культури: історія та сучасність: матеріали Всеукр. наук.-практ. конф., м. Київ, 25-26 березня 2021 р. Київ, 2021. C. 19-23.

2. Elam, K. Typographische Systeme. Princeton, USA: Princeton Architectural Press, 2009. P. 87-104.

3. Faroqi-Shah, Y., Gehman, M. The Role of Processing Speed and Cognitive Control on Word Retrieval in Aging and Aphasia. Journal of Language, Speech and Hearing Research. 2021. Vol. 64(3). P. 949-964.

4. Heer, J. et al. Graphical histories for visualization: Supporting analysis, communication, and evaluation. IEEE transactions on visualization and computer graphics. 2008. Vol. 14(6). P. 1189-1196.

5. Less Is More, or How Minimalism Changed Graphic Design: веб-caŭm. URL: https://medium.com/@,AprilHQ/less-ismore-or-how-minimalism-changed-graphic-design-b079a6bbb107 (дата звернення: 17.09.2021).

6. Patry, W. F. How to fix copyright. Oxford, UK : Oxford University Press, 2012. P. 56-79.

7. Smiciklas, M. The Power of Infographics: Using Pictures to Communicate and Connect with Your Audience. London: Que Publishing, 2012. P. 23-39.

8. Thorpe S. J. Image Processing by the Human Visual System. Advances in Computer Graphics, EurographicSeminars. 1991. P. 309-341.

9. Thorpe et al. Speed of Processing in the Human Visual System. Nature. Vol. 381. 1996. P. 520-522.

10. Van den Reek, A. The Effect of Visual Metaphor in Advertising at Different Processing Routes. Tilburg, Netherlands: Tilburg University, 2016. P. 1-72. 
11. Вежбовська Л. Р., Голубнича Г. В. Ефективність представлення масивів даних соціально значущої тематики за допомогою використання інфографіки. Дизайн-освіта як галузь креативних індустрій: матер. Всеукр. наук.-практ. конф., 18-19 квітня 2019 р. Київ: КНУКіМ, 2019. С. 108-113.

12. Young, James O. Art and Knowledge. Oxfordshire, UK: Routledge, 2013. P. 81-120.

\section{REFERENCES}

1. Bozhko T. O., Golubnycha, G. V. (2021). Vzaiemozviazok estetychnosti y informatyvnosti sotsialnoi infohrafiky [The Interconnection of Aesthetics and Informativity of Social Infographics]. Filosofiia podiievoi kultury: istoriia ta suchasnist: materialy Vseukrainskoi naukovo-praktychnoi konferentsii. Ukraine, Kyiv March 25-26 2021 [in Ukrainian].

2. Elam, K. Typographische Systeme [Typographic Systems]. Princeton, USA: Princeton Architectural Press, 2009. P. 87-104 [in German].

3. Faroqi-Shah, Y., Gehman, M. (2021). The Role of Processing Speed and Cognitive Control on Word Retrieval in Aging and Aphasia. Journal of Language, Speech and Hearing Research, 64(3), 949-964

4. Heer, J. et al. (2008). Graphical histories for visualization: Supporting analysis, communication, and evaluation. IEEE transactions on visualization and computer graphics, 14(6), 1189-1196

5. Less Is More, or How Minimalism Changed Graphic Design [online]. (2019). Available at: https://medium.com/@AprilHQ/less-is-more-or-how-minimalism-changed-graphic-design-b079a6bbb107

6. Patry, W. F. (2012). How to fix copyright. Oxford: Oxford University Press

7. Smiciklas, M. (2012). The Power of Infographics: Using Pictures to Communicate and Connect with Your Audience. London: Que Publishing [in English].

8. Thorpe S. J. (1991). Image Processing by the Human Visual System. Advances in Computer Graphics, EurographicSeminars

9. Thorpe et al. (1996). Speed of Processing in the Human Visual System. Nature, 381, 520-522

10. Van den Reek, A. (2016). The Effect of Visual Metaphor in Advertising at Different Processing Routes. Tilburg University

11. Vezhbovska, L., R., Golubnycha, G., V. (2019). Efektyvnist publichnoho predstavlennia masyviv danykh sotsialno znachushchoi tematyky za dopomohoiu vykorystannia infohrafiky [The Effectiveness of Public Presentation of Data Sets of Socially Significant Topics through the Use of Infographics]. Dyzain-osvita yak haluz kreatyvnykh industrii: materialy Vseukrainskoi naukovo-praktychnoi konferentsii. Ukraine, Kyiv April 18-19 2019 [in Ukrainian].

12. Young, James O. (2003). Art and Knowledge. Oxfordshire: Routledge 